\title{
Using Stakeholder Trusts to Reclaim Common Assets
}

\author{
Remarks by David Bollier* \\ Centre for the Study of Democratic Government \\ Oxford University Department of Politics
}

June 4, 2004

Thank you for inviting me to be with you today. Our objective here to find new ways to reduce inequality and to redistribute inheritance - is an admirable if daunting one. It could not be more urgent. The coming years will see the largest inter-generational transfer of wealth in history - literally trillions of dollars in assets. How this wealth is transferred - to whom, through what mechanisms, and in what magnitudes -- will have a profound influence on British life. It will affect the personal development and education of millions of individuals, the vitality of the economy, the quality of public life and the very character of British culture. So it is entirely appropriate that we address the policies that govern inheritance taxation with vigor and imagination.

Among philosophers and statesmen, it has long been a truism that popular ownership is indispensable to democratic capitalism. It has been said that the real trouble with capitalism is that it doesn't create enough capitalists. ${ }^{1}$ A key premise of this research project, "The New Politics of Ownership," is to address this problem. The benefits of capital ownership ought to be a right of citizenship, and inheritance tax policy should actively seek to facilitate that goal.

\footnotetext{
* David Bollier (www.bollier.org) is Editor of OntheCommons.org; Fellow at the Tomales Bay Institute (Point Reyes, California); Senior Fellow at the Norman Lear Center at the University of Southern California's Annenberg School for Communication; Co-founder of Public Knowledge, a Washington advocacy organization dedicated to the information commons; and author of Silent Theft: The Private Plunder of Our Common Wealth (Routledge, 2002) and the forthcoming Brand-Name Bullies and Their Quest to Own and Control Culture (John Wiley \& Sons).

1 This theme is developed extensively by Jeff Gates in The Ownership Solution: Toward a Shared Capitalism for the Twenty-First Century (Reading, Massachusetts: Addison-Wesley, 1998).
} 
In his paper for this workshop, Will Paxton has explored options for reform; others have probed public opinion about the different choices. In this paper, I will suggest that there are options that lie beyond inheritance policy that could provide a stream of non-wage income for the average citizen.

There is a whole class of overlooked sources of public revenue that I call "common assets." These are the resources that citizens collectively own but which are either being privatized by business or mismanaged by government, or both. If new revenues could be drawn from these common assets, they could be used to improve the economic security of millions of citizens and reduce the inequalities of wealth that afflict so many industrialized nations.

A key problem is that we do not usually recognize our common assets, which obviously makes it difficult to protect them, let alone generate revenue for the public good. Some of our most valuable assets include the electromagnetic spectrum used for broadcasting and wireless applications; the pollution-absorbing capacity of the sky; natural resources such as oil and minerals; and socially created wealth such as the financial liquidity of stock, scientific knowledge, and seignorage, which is the authority of banks to reap private profits by "creating money" through loans. (I will have more to say about these assets later.)

The political framing of this challenge requires our utmost attention. I understand that the British people appear to be skeptical if not hostile to increases in the inheritance tax. In the United States, American conservatives have skillfully encouraged a similar skepticism by re-naming inheritance tax as the "death tax." In the face of such loaded terms, I believe our first order of business is to re-frame the terms of debate. I prefer to speak about common assets, not public assets. This may seem like a trivial distinction, but in truth I believe a great deal flows from this shift of terminology.

\section{Why Talk About Common Assets?}

Public assets are resources that the government owns and manages, ostensibly for the benefit of the people. In fact, as we all know, public assets are frequently used to subsidize companies and to bolster the power of government or politicians. For example, government often gives companies cheap, direct access to oil and minerals, or the rights to government-funded scientific research. Revenues from broadcasters who buy the right to use the airwaves go 
directly into the treasury. These are not necessarily bad things, but let's be clear: they may not directly benefit the people.

Common assets are something else. They are resources that belong to the people, and so should benefit the people. The air, the human genome and fresh water are common assets that do not "belong" to the government. By their very nature, these resources belong to all of us, and should never be privately owned by corporations or mismanaged by government.

In the United States, there is a common-law doctrine of environmental law called the "public trust," which holds that the unorganized public is the sovereign owner of certain resources, and that government has no authority to seize or give away such resources. ${ }^{2}$ The concept has a particular resonance in the American political system, which is predicated on the preeminence of "We, the people," as the Declaration of Independence puts it, and not on the supremacy of government authority.

Talking about common assets instead of public assets serves two important goals: 1) It underscores the fact that the people, not the government, are the rightful owners and beneficiaries of "public assets," and 2) It associates these assets with an indispensable third sector of life that is distinct from government and the market. I call this neglected third sector "the commons."

Politicians and economists have long assumed that there are really only two sectors of power and value - markets and the state. Markets are supposed to be the vehicle for economic progress while government is supposed to take care of everything else. Increasingly, however, it is becoming clear that the commons is at least as important to our well-being. The commons is a generic term that refers to a wide array of creations of nature and society that we inherit freely, collectively use and share, and hold in trust for future generations.

Nature may be the most obvious set of physical commons - the atmosphere, the human genome, agricultural seeds, fresh water supplies, wildlife, ecosystems, and much else. Some commons, such as libraries, national parks, public spaces and academic communities, are social creations. Still other commons are intangible, like information and creative works. This might seem

\footnotetext{
2 See, e.g., Mark Dowie, "In Law We Trust," Orion, July/August 2003, pp. 19-25; or Charles F. Wilkinson, "The
} Headwaters of the Public Trust: Some of the Traditional Doctrine," Environmental Law, Spring 1989, pp. 425-471. 
like a rather elastic use of the term. I consider it analogous to "the market," which itself is a generic term that is used to refer to a wide variety of economic phenomena such as the stock market, retail stores, exchanges of intellectual property and lemonade stands.

Talking about the commons is not a matter of rhetoric, but rather an important conceptual re-ordering. To talk about the commons is to re-frame the moral and property claims associated with resources that morally or legally belong to all citizens. Market discourse sneers at inheritance taxes as "redistribution." But if you begin to inquire into how a lot of inherited wealth was generated in the first place -- by enclosing the commons and privatizing assets that belong to everyone ${ }^{3}$-redistribution is not really an accurate term. For many resources, it is more appropriate to talk about reclaiming that which was ours in the first place.

So as we approach the issue of inheritance tax policy, let's not simply take the outcome of market activity as the starting point of discussion. To do so simply invites critics to characterize inheritance taxes as an odious theft known as "income re-distribution." I'd prefer to talk about prior thefts of the commons that culprit industrialists prefer to mischaracterize as entrepreneurial brilliance. This is the focus of my book, Silent Theft: The Private Plunder of Our Common Wealth (Routledge, 2002), which surveys the wide range of common resources (mostly in the United States) that government has quietly given away and companies have privatized, to the detriment of the people.

If we are going to talk about inheritance tax policy, there is another reason that we need to talk about common assets. They comprise a much larger storehouse of wealth than private inheritances. Our legacy from earlier generations is far larger than any private inheritances that we collectively receive (if we're lucky). Think about it: We are born into a world of orderly towns, stable political institutions, municipal services, schools, an enormous store of knowledge and a natural environment that is perfectly calibrated to sustain our lives and that of God's creation.

The market tends to ignore the actual value of these common resources so long as they are illiquid. It is the conceit of neoclassical economics that resources acquire value only when they are bounded by private property rights and traded in markets. As my colleague Jonathan Rowe has put it, the world is

\footnotetext{
3 This history has been most astutely documented by Karl Polanyi in his seminal The Great Transformation (Beacon Press, 1944, 1957).
} 
void and without form until the market waves its hand over the nothingness and declares, "Let there be stuff!" This is why the public domain in arts, culture and science is regarded as a junkyard of worthless, antiquated works - while copyrighted material is regarded as valuable. To investors, land that has not been developed is non-productive and under-leveraged - while wilderness is regarded as a wasteland. Time is money, according to market discourse, and behaviors that do no maximize our individual material utility are "irrational."

To talk about the commons, then, is to identify a significant blind spot in our consciousness and name things that have gone unnamed in neoclassical economic discourse and the dominant strains of public policy. The commons also helps us recognize that our shared inheritance is being grossly mismanaged. Maintenance is terrible, theft is rampant and rents often aren't being collected.

The first step that any responsible owner takes is to conduct an audit to document the state of our property. That's what companies do all the time. So a number of us in the United States recently got together and decided, Why not conduct our own annual audit on the state of our common assets? We thought it was about time that our common assets receive the same care and sophistication that private assets are generally accorded. Last year we published the results in our first annual report, The State of the Commons, 2003/2004, which surveys the health of our major common assets. ${ }^{4}$

Our report looks at six broad categories of commons - the sky, airwaves, water, culture, science and quiet. There are literally dozens more, ranging from public lands and scientific knowledge to fresh water supplies and the human genome. The recurrent problem in most commons is that the market is behaving like a runaway steam engine. It has no internal governor to tell it when to stop depleting the commons that sustain it. The market finds it convenient to draw down our common capital (after all, it is often "free" for the taking), but the accounts ledger commits a fraud when it calls this draw-down income rather than capital depletion.

We don't need to accept this deception. If we can begin to identify and acknowledge our common assets, we can start to make reasoned judgments about how to protect them and, if appropriate, use them sustainably. If we're careful, the public may even begin to reap some money from its previously unacknowledged assets!

\footnotetext{
4 Friends of the Commons, The State of the Commons, 2003/2004, available at http://www.friendsofthecommons.org.
} 
It should be emphasized that not all common assets should be exploited as revenue sources. Many of them should be preserved intact and enjoyed for their natural, social and aesthetic benefits. Wilderness areas, parks, and the public domain of cultural works should be regarded as inalienable possessions of the public, and should not be propertized, monetized or privately controlled. Stonehenge is not a mere tourist attraction, it is a national treasure that is associated with British identity. The human genome is not a mere commodity, but a part of the "common heritage of humankind." The coastline, too, has value that exceeds any market price, and is a legacy that we are morally bound to pass on to future generations.

\section{Using Common Assets to Address Inequality}

If, however, a resource can be "assetized" in an ecologically and socially benign way, we should explore the best institutional vehicles for doing so. We should adopt a basic principle - that any monetary value should be captured for public use and shared with as many citizens as possible. Cash value should not be diverted for private gain without a corresponding public benefit.

British economist James Robertson, a cofounder of the New Economics Foundation, calls this strategy "pre-distribution" and contrasts it with "redistributionist" policies. He writes:

Whereas redistribution aims to correct the outcomes of economic activity after the event, predistribution shares the value of essential inputs to economic activity. Whereas redistribution is dependency-reinforcing, predistribution is enabling. Because it addresses the underlying causes of economic injustice, inequality and exclusion, predistribution is an essential feature of a prosperous economy in an inclusive society. It reverses the private 'enclosure' of common resources on which so much conventional economic development has been based. - and still is. ${ }^{5}$

Corporations have a long history of expropriating the commons and then privatizing the surplus gains for themselves. ${ }^{6}$ To be sure, most

\footnotetext{
5 James Roberstson, “The Alternative Mansion House Speech,” April 9, 2000, available at http://www.wwdemocracy.nildram.co.uk/democracy_today/alt_mansion.htm.

6 See, e.g., The Ecology, Whose Common Future? Reclaiming the Commons (Philadelphia, PA: New Society Publishers, 1993); and David Bollier, Silent Theft: The Private Plunder of Our Common Wealth (Routledge, 2002).
} 
industrialized nations have bravely tried to ease some of the resulting hardships through various social services, i.e., the "welfare state." But in societies based on the supremacy of the market, these programs are often reviled and politically vulnerable. Government funding is frequently portrayed as a "subsidy" that distorts the "free market." Or it is cast as a morally tainted "giveaway" that erodes people's "work ethic."

The virtue of a common assets approach is that it restores some measure of equity to commoners without becoming entangled in the familiar politics of "income redistribution." The moral burden is shifted. The politics of the commons is about ordinary people reclaiming what rightfully belongs to them. By asserting collective ownership over their common assets and sharing the dividends, citizens do not need to recoil in shame that they are receiving a "government handout." They are proudly claiming dividends due to them as a civic entitlement. Such dividends provide citizens with a valuable, regular supplement to wage income, enhancing them to enjoy greater personal security and to "invest in themselves" through education or entrepreneurial ventures.

The benefits of "predistribution" from common assets are especially important to today's young people and, odd as this may sound, babies. As Professors Bruce Ackerman and Anne Alstott have shown in their book, The Stakebolder Society, one of the preeminent obstacles facing young people is acquiring the capital to finance their educations or start a business. ${ }^{7}$ The burdens of debt on young people can be crushing, which means that those children who come from affluent families and inherit money have much greater opportunities. ${ }^{8}$ Inequity replicates itself from one generation to the next, and indeed grows worse. That is why it is certainly encouraging to see the British government considering the "Baby Bond" as a fresh approach to this problem. ${ }^{9}$

\footnotetext{
7 Bruce Ackerman and Ann Alstott, The Stakeholder Society (New Haven, Connecticut: Yale University Press, 1999).

8 Brendan I. Koenrer, “The Ambition Tax: Why America's Young Are Being Crushed by Debt and Why No One Seems to Care," The Village Voice, March 17-23, 2004, available at http://www.villagevoice.com/issues/0411/koerner.php.

9 See Will Paxton, Equal Shares? Building a Progressive and Coherent Asset-Based Welfare Policy (Institute for Public Policy Research, 2003). For American proposals along the same lines, see the work of Ray Boshara at the New America Foundation's Asset Building Program (http://www.newamerica.net). Also, Jonathan Rowe, "Every Baby a Trust Fund Baby," The American Prospect, January 1-15, 2001, available at http://www.prospect.org/web/printfriendly-view.ww?id=4589.
} 
But how to finance such schemes in a politically feasible way? In general, common assets represent a politically attractive financial base for a new set of universal grants. There is a danger, as mentioned earlier, that our enthusiasm for new revenue sources could drive policymakers to over-exploit fragile or depletable natural resources. This is not an insurmountable problem, but it is one to bears close attention. That is why the institutional governance of common assets is so critical. Equitable benefits and long-term preservation must be twin goals in managing common assets.

\section{The Stakeholder Trust and the Commons}

In thinking about how to manage a common asset and distribute its revenues, our first reflex might be to assign such responsibilities to a government agency. But the history of government stewardship of common assets should give us pause. Government regulation is fraught with the deep, enduring problems of politics, bureaucratic (mis)management, secrecy, and barriers to democratic participation. Many of these are structural issues, not isolated problems of agency leadership or under-funding.

This is not to summarily reject government as a potential steward of common assets, but rather to raise the question: Are there superior alternatives? In many instances, I believe there are. I believe that the nonprofit trust is a time-tested institutional structure that could be adapted to manage a great many common assets in effective, accountable ways. My colleague Peter Barnes has instructed me a great deal on this point. ${ }^{10}$ Barnes argues that if the corporation is the preeminent institution of the market sector, the trust is the preeminent institution of the commons. Barnes contends that the stakeholder trust is one of the most promising vehicles for re-inventing the commons in the $21^{\text {st }}$ Century.

The main arguments for trusts as an alternative to government stewardship are the following:

- Government has been the default trustee of common resources for several hundred years and has clearly failed to protect the assets in question, much less to assure that stakeholders receive the benefits owed to them.

\footnotetext{
10 Peter Barnes founded the Tomales Bay Institute, devoted to the commons; cofounded the socially responsible telephone company Working Assets; and is the author of Who Owns the Sky? Our Common Assets and the Future of Capitalism (www.skybook.org). His thoughts on trusts can be found in Who Orens the Sky? and in "Capitalism, the Commons and Divine Right,” 23 ${ }^{\text {rd }}$ Annual E.F. Schumacher Lecture, Stockbridge, Massachusetts, October 25, 2003. A print version is available from the E.F. Schumacher Society, at http://www.smallisbeautiful.org.
} 
- Sound government policymaking and regulatory enforcement have been irredeemably corrupted by profit-maximizing corporations.

- While stakeholder trusts could conceivably be corrupted as well, their institutional structure has stronger safeguards. Specifically, trusts are explicitly charged with preservation of the asset and trustees have clearly defined fiduciary responsibilities. In trusts, decisionmaking is more transparent and accountability more easily enforced than in government.

- Finally, trusts have a more focused mission than government. This makes it easier to see where revenues and expenditures are going, which improves financial accountability. Government simply has too many complex, intermingled revenue streams for the general public or the press to monitor. Government also has so many complex tasks to perform at once - scientific research, administrative coordination, the political brokering of interests, law enforcement, etc. - that corporations with political clout are far better positioned to advance their own interests at the expense of citizens.

Trusts with well-defined missions are less likely to suffer from these problems. They have distinct beneficiaries who have a keen self-interest in monitoring a trust's performance and clearer legal standards for responsible performance.

There are, of course, a wide variety of trusts. The National Trust here in the United Kingdom is an excellent example of how a trust can preserve a common asset in perpetuity for the benefit of all. It is the trustee for more than 200 historic homes, 612,000 acres of countryside, and 600 miles of unspoiled natural coastline.

In the United States, land trusts are a popular vehicle for preserving forests, farmlands, beaches and other priceless natural resources. Two of the leading private land trusts in the U.S. are the Nature Conservancy and the Trust for Public Land. There are also agricultural land trusts, which buy conservation easements from farmers to prevent development of the land, preserve the countryside and bolster the farm economy. At the local level, community gardens are a form of trust that rejuvenate neighborhoods and let citydwellers enjoy gardening. 
While many trusts are not structured to generate revenues, but rather to preserve the asset and assure fair access and use of it, the stakeholder trust offers an excellent vehicle for doing so.

In the United States, state land trusts generate revenues from more than 150 million acres that they administer. Much of this land is leased for timber, grazing or oil production, with revenues going to public schools. One example is the Texas Permanent School Fund, which gives the proceeds from oil and gas leases on submerged Gulf Coast lands to local schools. The overall sums generated from these lands are huge. In 1996, twenty-two states earned $\$ 3$ billion from the leasing of 135 million acres of land. ${ }^{11}$ At the national level, the Land and Water Conservation Fund has used revenues from offshore oil and gas leases to acquire about seven million acres of wilderness, park land and open spaces, and to fund development in more than 37,000 state parks and recreation projects. ${ }^{12}$

One of the more ingenious revenue-generating trusts is the Music Performance Trust Fund, which was formed in 1948 through an agreement between the recording industry and the musicians' union. ${ }^{13}$ Musicians who played in live performances were worried that the expansion of recorded music would weaken the musical communities that nurture and sustain musicians. Under the agreement, a small percentage of record sales goes into a fund that pays for free concerts in schools, parks and hospitals, as well as for musical appreciation and education programs.

Perhaps the biggest, most successful stakeholder trust is the Alaska Permanent Fund, a state-run investment savings account that pays equal annual dividends to every Alaskan citizen; last year each citizen received \$1,107.56. The Fund was established in 1976 by a voter-approved amendment to the state constitution requiring that at least 25 percent of revenues from certain minerals

\footnotetext{
11 Helen Payne Watt, Common Assets: Asserting Rights to Our Shared Inhereitance (Washington, D.C.: Corporation for Economic Development and Redefining Progress, 1999), p. 16.

12 The home page for the Land and Water Conservation Fund is http://www.nps.gov/lwcf. The chief defender of the Land and Water Conservation Fund is an organization, "Americans for Our Heritage and Recreation," at www.ahrinfo.org.

13 The home page for the Music Performance Trust Fund is http://www.mptf.org/home.
} 
on state lands go to the trust. ${ }^{14}$ Much of the Fund's revenue has come from oil drilled on the state's North Slope.

A noteworthy benefit of the Fund's dividends, beyond their egalitarian distribution, is the economic fillip to the Alaskan economy. Instead of oil revenues being siphoned away by outside investors, the Fund's dividends are used largely within the state, and so have a multiplier effect on the state's economy. In May 2004, the market value of the Fund's investments was nearly $\$ 27$ billion, making it one of the hundred largest investment funds in the world. The U.S. Basic Income Guarantee Network, an organization that advocates governments to help give all citizens enough money to live on, called the Alaska dividend "the only example of an existing basic income guarantee in the world today." 15

The Alaska Permanent Fund has been so successful that after the United States invaded Iraq, Vernon L. Smith, the 2002 Nobel Laureate in Economics, called on the Bush Administration to establish an Iraqi People's Fund to distribute the nation's vast oil revenues to the Iraqi people. Smith wrote: "This is the time, and Iraq is the place, to create an economic system embracing the revolutionary principle that public assets belong directly to the public - and can be managed to further individual benefit and free choice, without intermediate government ownership in the public name."16 Despite Secretary of State Colin Powell's enthusiasm for the idea, the idea of an Iraqi People's Fund was not adopted.

Still, the idea of harnessing common assets to generate revenues is nothing if not irrepressible. It inspired Peter Barnes' ingenious idea to establish a "Sky Trust" to generate revenues from the "scarcity rent" of the sky. The scarcity is the sky's limited capacity to absorb carbon-based pollution. The potential rent to be earned from this scarcity would come from "propertizing" the sky and auctioning off the right to pollute specific units of carbon-based emissions. By assigning property rights to the waste-absorbing capacity of the sky - a scarce resource - a new revenue stream can be created.

\footnotetext{
14 The home page for the Alaska Permanent Fund is http://www.apfc.org. See also a history of Walter Hickel, Crisis in the Commons: The Alaska Solution (Institute for Contemporary Studies, 2002).

15 Sam Bishop, "Hammond Advocates Dividend for Iraq," Fairbanks (Alaska) Daily Neres-Miner, February 27, 2004.

16 Vernon L. Smith, “The Iraqi People’s Fund,” The Wall Street Journal, December 22, 2003.
} 
Congress took a small step in this direction in 1990 when it established a "cap-and-trade" system for sulfur dioxide emissions, the chief cause of acid rain. The government set a steadily declining a "cap" on how much overall pollution could be emitted. Power plants were then given tradeable rights authorizing them to emit sulphur dioxide into the atmosphere. This gave power plant owners the discretion to use their free rights to pollute, or to sell them to others for a price and pocket the cash.

While this system of "pollution rights" has been remarkably successful in forcing companies to reduce pollution in efficient ways, it contains a terrible flaw. It gave away the rights to pollute to companies for free! It assumed that existing polluters should pay no price for polluting a natural resource that, after all, belongs to all of us. Barnes' book, Who Owns the Sky?, makes this point. ${ }^{17}$ We all own the sky, and we all should be able to reap any financial benefits that may be available from giving property rights to polluters.

That is where the Sky Trust idea comes in. Barnes proposes that polluters be forced to pay at auction for their rights to pollute, with the money deposited into a stakeholder trust owned by all citizens. Every citizen would get one share. To assure that all citizens would benefit indefinitely, shares would not be transferable, but be associated with citizenship itself.

The Sky Trust model makes compelling economic sense on many levels. It forces polluters to pay a price for dumping wastes into the commons, and so encourages them to find innovative ways to reduce their pollution. In the short run, this is likely to raise the price of carbon-based products. But the Sky Trust also has the economic virtue of returning to consumers the extra money that they spend on carbon-based products, and in an equitable way: Those who conserve fuel will recoup a greater proportion of their fuel expenditures than those who drive SUVs.

The Sky Trust is essentially a stakeholder trust that is applied to a "waste sink," the sky, instead of to a physical asset like oil. The trust is a vehicle by which polluters are forced to pay pollutees. Of course, we are all polluters and pollutees. But as Barnes notes, "Stakeholder trusts tied to waste sinks can penalize us when we pollute and compensate us when we are polluted upon. They can treat us as both sinners and victims, and keep track of the proportions, incrementally penalizing bad behavior and rewarding good

17 Peter Barnes, Who Owns the Sky? Our Common Assets and the Future of Capitalism (Washington, D.C.: Island Press, 2001). See also the website, http://www.skytrust.org. 
behavior. In short, stakeholder trusts can be used to achieve two ends simultaneously: preservation of nature and greater equity among humans."

\section{The Design of Stakeholder Trusts}

In designing trusts, it is important that they be structured to assure accountability to stakeholders. Besides requiring the utmost openness in deliberation and reporting, the creators of any trust must decide: 1) Who are the stakeholders/beneficiaries of the trust to which it should be accountable? 2) Who shall appoint the trustees? 3) What procedures and standards shall govern the activities of the trust? 4) Where do the trust's revenues come from? and 5) What is the distribution formula for the trust's dividends (if revenuedistribution is a purpose of the trust)?

The proper beneficiaries of most common assets ought to be the general citizenry, or the members of a defined community. Trustees could be appointed by the top elected officials or they could be elected by beneficiaries, but in any case they must have clear fiduciary responsibilities to stakeholders. The founding charter should stipulate the criteria and procedures for making decisions

Most stakeholder trust proposals have proposed that their revenues come from the general treasury - i.e., taxes - which is an entirely logical source of funding. But capturing revenue from common assets may be more politically appealing because, as noted above, it bypasses the familiar complaints about "income redistribution."

The argument for a stakeholder trust based on common assets is this: All citizens are joint owners of common assets that, if suitable for market use and properly priced, should be used to generate income that is distributed in equal amounts to everyone. For finite common assets that provide valuable ecosystem services (such as waste sinks like the sky), proper pricing is necessary to protect them from overuse and to assure equitable benefits flowing from them.

Well-structured stakeholder trusts could achieve a significant advance over the traditional social services of the welfare state. As Peter Barnes writes: "Whereas social insurance mainly helps people late in life, the fruits of common assets would help people early in life and throughout life. Such assets wouldn't just be safety nets, they'd also be ladders. They'd temper the maldistribution of 
private wealth without disturbing it, increase individual and family security, and provide hope and opportunity where those have been lacking. And unlike public assistance, they'd come as part of...citizenship, with no means testing and no bureaucrats asking questions." 18

\section{Trusts as a Solution to Market Externalities}

A final word must be said about the virtue of stakeholder trusts. Not only do they ameliorate inequality of wealth and opportunity, they represent a structural solution to the problem of "market externalities," one of the most tenacious problems of modern-day capitalism. Market society's consumption of nature's resources over the past century has been mind-bogglingly vast, and is simply unsustainable. ${ }^{19}$ Yet to the neoclassical economic mind, ecological harm is an "externality" - an unintended side-effect that is a mere sideshow to the main act of market exchange.

Economists and policymakers are loathe to admit that profit-maximizing corporations are programmed to externalize as many costs as possible. Ecological damage, community disruption, and discriminatory service based on profitability are structural features of market activity. They are a pathology, actually, for which the neoliberal state must spend an inordinate amount of effort and money to mitigate.

In 1920, the economist Arthur Pigou first suggested that government could use taxes to discourage pollution. In essence, government could set an artificial price to represent the value of externalized costs, and this could be integrated into market decisions. ${ }^{20}$ Unfortunately, Pigovian taxes have never really caught on, in part because corporations have usually had the political clout to resist new taxes.

Another proposal, made by economist Ronald Coase, has made greater headway in dealing with externalities, and that is the idea of assigning property rights to externalities. ${ }^{21}$ Tradeable pollution rights are a perfect example. Coase

18 Peter Barnes, Who Owns the Sky? p. 122.

19 See, e.g., J.R. McNeill, Something New Under the Sun: An Environmental History of the Twentieth-Century World (New York, NY: W.W. Norton, 2000).

20 Arthur C. Pigou, The Economics of Welfare (London: MacMillan, 1920).

21 Ronald Coase, “The Problem of Social Cost," The Journal of Law and Economics, Vol. 3, pp. 1-44, Chicago, 1960. 
did not really pay much attention to who should be given the property rights in the first place. But as Peter Barnes has pointed out, it makes a huge difference whether they are owned by polluters or pollutees. So far, the United Kingdom, the European Union and the United States have been giving tradeable pollution rights to polluters. This represents a large and unjustified transfer of wealth to corporations whose only claim to this wealth is that they have polluted in the past. After all, the earth, air and water does not preemptively belong to polluters, but to all of us.

Here's where stakeholder trusts offer an effective solution. Property rights could be assigned to pollutees, future generations, and/or nature, and a stakeholder trust could manage these rights $n$ behalf of the stakeholders. The trust could limit pollution to thresholds the sinks can safely absorb, and charge polluters for using the sinks up to the thresholds. This would force corporations to internalize many externalities. The pleasant side effect would be a revenue stream that benefits the designated stakeholders.

The Sky Trust model demonstrates that stakeholder trusts aren't just a way to equalize household income. They are also a way to make corporations internalize externalities and respect nature. And they can do this efficiently, with minimal transaction costs.

Trusts have the virtue of dealing with the problem of market externalities in a more direct, forthright fashion than the privatization of government services. Champions of privatization usually do not own up to the truth that the purported innovations and efficiencies in service-delivery may require unpleasant externalizations of costs (substandard wages, corner-cutting on quality, reduced capital expenditures, etc.) If government can sometimes be stodgy and unresponsive in providing public services, privatization has a propensity to "skim the cream" from a resource while shirking actual long-term costs and universal service. ${ }^{22}$ I believe trusts offer an attractive institutional alternative.

In fact, with sufficient government support, stakeholder trusts could represent a robust third sector of the economy, side by side with markets and government. Their role would be to own and manage inherited natural and social assets on behalf of key stakeholders whose interests are often harmed by

22 See, e.g., the April 2004 issue of The New Internationalist on “The Great Privatization Grab," available at http://www.newint.org/issue355/contents.htm. 
the market, such as pollutees, children, seniors, future generations and nature. It may be premature to declare that trusts can serve these constituencies better than government programs; that may require a case-by-case reckoning. But at a time when the integrity and competence of government bureaucracies are in question, the trust model offers an attractive alternative for fostering transparency, accountability, social equity and environmental protection.

\section{Developing a Common Assets Strategy in Great Britain}

What remains is to suggest how stakeholder trusts might be introduced more broadly in Great Britain to manage common assets. Since I am an American, I may not be the best advisor to you on this topic. But speaking generally, I believe there are four distinct challenges:

1. To develop a commons discourse that re-frames the political debate away from "income redistribution" to a focus on reclaiming common assets;

2. To determine which common assets can be managed by stakeholder trusts, and which are suitable for market exploitation;

3. To craft tailored policy mechanisms to protect the long-term health of a given resource and allow efficient market use while that the full benefits accrue to citizens; and

4. To organize political campaigns to wrest control over common assets from government and markets and assign them to commons-friendly institutions such as trusts.

Fortunately, there are some precedents for using public policy to generate revenues from common assets. The biggest success story may be auctions for licenses to use the airwaves for broadcasting and wireless services. The Radiocommunications Agency has determined that the value of the spectrum to the U.K. economy as a whole is more than $£ 20$ billion a year, and over 2 percent of the UK output. The use of auctions to wring maximum value from the airwaves was a singular innovation of the 1990s in both the United States and the United Kingdom.

It is worth noting that the sums deposited into the government treasury from these auctions are an important step toward reclaiming common assets. 
But it is worth inquiring whether the people really benefit, or merely the government, from the sale of property rights in spectrum. There may be more efficient, remunerative or democratically appealing ways of capitalizing on the spectrum. For example, as Yale Law Professor Yochai Benkler argues, the citizenry's interest in innovation, access to the spectrum and free speech interests may be better served by using the spectrum as a commons. ${ }^{23}$

Natural resources are another type of common asset that British policymakers might wish to use to generate new revenues. The Alaska Permanent Fund may be the best guiding example. Financial Times columnist Samuel Brittan proposed in the late 1970s that state revenue from North Sea oil should be earmarked for citizen dividends that could be capitalized on the stock market. ${ }^{24}$ Unfortunately, this opportunity was squandered.

But there are other opportunities. Tapping into the scarcity rents of waste sinks - the Sky Trust model - bears exploration. The economic logic is compelling; the equitable distribution of revenues is attractive; and industrialized nations will need to take effective action sooner rather than later to curb carbon emissions. Why not inaugurate this new model now and learn how it might be replicated to address other types of pollution? In the United States, a version of the Sky Trust proposal has been introduced in Senate legislation sponsored by Senators McCain and Lieberman. While it is not likely to pass during any Bush Administration, support for it continues to grow, especially as national governments and corporations begin to take global warming more seriously.

Land value taxation is a strategy that certainly deserves greater attention. The idea is that increases in the "socially created value" of land should be recouped by the people, and not simply privatized by developers. Economist David Ricardo and American social reformer Henry George, the author of Progress and Poverty (1879) were among the first to realize that the scarcity value of land owes very little to individual effort but a great deal to the community, especially government when it builds major public facilities like subways or office complexes. Samuel Brittan noted the case of office real estate in South London that was bought in 1980 for $£ 100,000$ and sold in January 2000 for

\footnotetext{
23 See "Spectrum Commons" portion of Professor Yochai Benkler website at http://www.benkler.org/Pub.html\#Spectrum; also, "Freeing the Airwaves," The Economist, May 31, 2003.

24 Samuel Brittan, "The Logic of the Baby Bond," August 3, Review of Equal Shares? Building a Progressive and Coherent Asset-Based Welfare Policy, edited by Will Paxton, available at http://www.samuelbrittan.co.uk/text159_p.html.
} 
$£ 2.6 \mathrm{~m}$, an increase in value that stemmed from the government's construction of the Jubilee line. Why should this phenomenal increase in value be pocketed by private developers when the public, or the government, played a major role in the value of the land?

One of the most innovative proposals for capturing revenues from common assets comes from German sociologist Joseph Huber and British economist James Robertson, cofounder of the New Economics Foundation. Their 2000 report, Creating New Money, notes that the British government has essentially forfeited the authority - and revenues - that come from issuing new non-cash money into circulation. ${ }^{25}$ While the government pays for manufacturing banknotes and coins, banks are the more significant player in "creating money" by their ability to make interest-bearing loans, the cornerstone of their profits.

The right to issue new money, called "seigniorage," was traditionally the right of monarchs and local rulers. But today, about 95 percent of new money in the U.K. is issued by private commercial banks, not governments. By failing to capture revenues from seigniorage, the British government loses an estimated $£ 47$ billion a year, Huber and Robertson estimate. Commercial banks enjoy "a hidden subsidy in the shape of special, supernormal profits of the order of $£ 21$ billion a year in the U.K. The government's abdication of the authority to create new money costs the public treasury the equivalent of an extraordinary twelve pence on income tax in the U.K., write Huber and Robertson. "In effect it has become a subsidy to the private banking sector - a nice little earner, but one that should always have been for public benefit rather than private gain.”

The authors urge that central banks should create the amount of new non-cash money and credit it to government as public revenue, which it will put into circulation by spending. Banks would function was credit brokers, essentially financial intermediaries. The case for seigniorage reform is a novel, unfamiliar departure, but it is intriguing and deserves consideration.

In a similar vein, it is worth contemplating how the taxpaying public might reap some revenues for its role in maintaining public financial markets. Taxpayers pay for the administrative agencies and judicial bodies that allow

\footnotetext{
25 Joseph Huber and James Robertson, Creating New Money: A Monetary Reform for the Information Age (New Economics Foundation, 2000), available at http://www.neweconomics.org/gen/z_sys_PublicationDetail.aspx?PID =81.
} 
public markets to operate and be trustworthy. What is the value of this common asset? One indication is the premium that accrues to the investors and underwriters when a privately held company "goes public" through an initial public offering (IPO) of stock. The market valuation of such a company can soar overnight by at least 30 percent. This premium stems from the ability of the corporate asset to be turned into cash - made liquid - much more readily.

But this liquidity premium is not generated by the company itself, or from the CEO, but from society - specifically, from the public stock market and the entire infrastructure of government, financial institutions and media that backs it up. Yet the people who profit from an IPO are private shareholders, who get large capital gains, and underwriters, who get fees. Why shouldn't taxpayers get a small slice of the action - say 5 percent - which could be placed in a public trust resembling a mutual fund? Shares could be assigned to every citizen, along the lines of the Alaska Permanent Fund, and be designated for retirement, college education or some other social need.

As the foregoing suggests, stakeholder trusts are a versatile instrument for reclaiming common assets. But whether they will actually be introduced to achieve this end will depend a great deal on political leadership and the mobilization of the public and key constituencies. This is another, more complicated issue beyond the scope of this paper.

But hopefully, by raising the issue, this workshop might begin to energize a larger set of players who can move a "common assets" agenda forward. It is a fresh critique with sound economic backing and enormous political appeal. It is also a feasible progressive agenda for reducing inequalities of wealth without sparking the familiar controversies over income redistribution. To be sure, many policy details must be worked out, but the overarching vision and re-framing of discussion can help move the common assets agenda a long way forward. 